\section{UK animal labs still under siege}

Construction work restarted last week on a biomedical research facility at the University of Oxford. Completion of the centre has been delayed for 18 months because of protests by animal-rights groups.

The original building contractor pulled out in July last year because of threats to its workers. Since then, no work has been carried out on the building, which should have been completed last autumn.

The university had always stressed that it would proceed with the facility, which will replace and upgrade most of its animal housing. It has engaged new contractors whose identities are being kept secret - although one animal-rights group says it can and will reveal them. On 30 November workers delivered building material to the site under police protection. Complex and expensive security arrangements have been put in place to protect contractors and the site.

The travails of the $£ 20$-million (US $\$ 35$-million) project typify the problems that British scientists who use animals in their research have had to face in the past three decades of pressure from extremist animal-rights groups. In the past ten years, activists have started to target individual scientists - this has created a sort of siege mentality.

But official figures show that in the past year or so the number of extremist attacks has fallen. New laws proposed shortly after the halt to building work in Oxford last year have helped. Introduced this summer, they make it illegal to protest outside people's homes if this causes "harassment, alarm or distress", and to use harassment to inflict economic damage on a company. At the same time researchers have changed tactics. Instead of avoiding the public eye, they are being more open about their work and educating the public about the benefits of animal research to medicine.

But an informal survey by Nature reveals that the trauma of the past few decades still has effects. The possibility of personal risk puts strain on researchers, their institutions and the relations between the two. Nearly all those who spoke to Nature asked for their names not to be published.

One result of continuing tensions is that

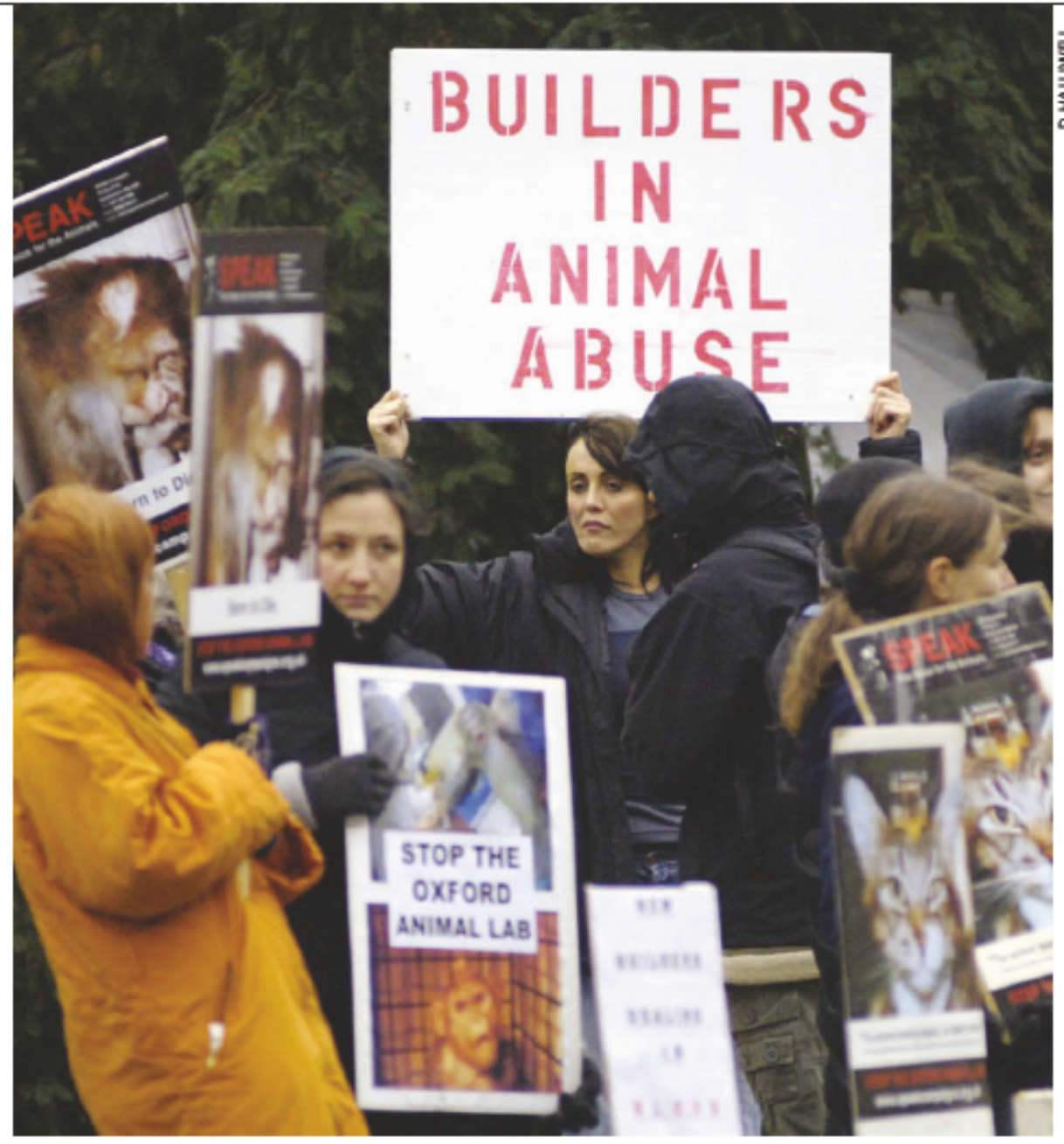

Building tension: contractors in Oxford hope that anonymity will allow them to evade protestors.

those entering a scientific career prefer not to work with animals. "Very few people are willing to stake their career on primate science or whole-animal studies," says one primate researcher from a major university. Technicians for animal houses are also hard to recruit, often being put off by the security measures. "Who would be prepared to go exdirectory with their home phone, have their car deregistered with the licensing authority and learn what to do if they are followed? ${ }^{m}$ asks one animal-house manager.

Fearful of the risks to their staff and property, some universities have been careful to keep their animal research low profile. Around ten universities continue to support primate facilities, but one neuroscientist at anotherbig research university says he gave up after becoming the only one using them. ${ }^{\alpha}$ There was no absolute ban," he says, "but it was not encouraged because it was seen as producing a risk to the university.

For the same reason, universities are loath to do building work on animal housing, although there is no suggestion that animal welfare has been compromised. "The infrastructure here is getting old," says a physiologist using mice at a major university. "We are upgrading, but the nature of that upgrade is determined by needing a low profile."

Researchers also say they are hampered by the UK Home Office's strict regulations on animal research. "Iwouldn't do this personally," says a senior neuroscientist at one large research

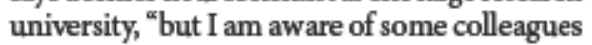
who go to mainland Europe, because they feel there are too many hoops to jump through in Britain." He says primate experiments have been taken abroad to avoid Home Office rules that were introduced after the projects had been approved by funders.

Roger Morris, head of biochemistry at King's College London, acknowledges the problems still facing researchers, but says things have improved. "The Home Office paperwork has got better, and the scientific community is more willing to stand up for what they do."

Tom Simonite and Jim Giles 